\title{
Transforming Growth Factor- $\beta 1$ Expression and the Role of Angiotensin-converting Enzyme Inhibitor on Perianastomotic Intimal Hyperplasia in Polytetrafluoroethylene Graft Implanted in Rabbit Carotid Artery
}

\author{
JUN WON UM, JONG MAN KIM, BYUNG WOOK MIN, YOUNG SIK KIM*, GIL SOO SON, \\ JAE BOK LEE, SUK IN JUNG, SEUNG JOO KIM, SANG YONG CHOI, \\ BUM HWAN KOO, NOBUYA ISHIBASHI**, KAZUO SHIROUZU** \\ AND CHUNG WUNG WHANG
}

\begin{abstract}
Departments of Surgery and Pathology*, Korea University College of Medicine, Seoul 136-705, Korea and ${ }^{* *}$ Department of Surgery, Kurume University School of Medicine,
\end{abstract}

Kurume 830-0011, Japan.

\begin{abstract}
Summary: The purpose of this study was to evaluate the relationship between intimal hyperplasia and transforming growth factor- $\beta 1$ (TGF- $\beta 1$ ) mRNA expression in synthetic arterial grafts and also to clarify the effect of angiotensin-converting enzyme inhibitor (ACEI) on perianastomotic intimal hyperplasia and TGF- $\beta 1$ mRNA expression. Thirty New Zealand White rabbits were randomly divided into two groups (15 each); one group was administered Captopril $10 \mathrm{mg} / \mathrm{kg} / \mathrm{day}$ per os as an ACE inhibitor, and the other group received on saline as a vehicle from 7 days prior to operation until the graft was harvest $(1,8$, or 14 weeks). A 10-mm segment of an expanded polytetrafluoroethylene graft ( $3 \mathrm{~mm}$ in diameter) was implanted in the right common carotid artery of the rabbits; 15 rabbits had by-pass grafting alone (Graft Alone group) and the other 15 rabbits had by-pass graft along with the ACEI (Graft plus ACEI group). The artery grafts were harvested. The intima to media height ratio (IMHR) and the TGF- $\beta 1$ mRNA expression level in perianastomotic graft tissue by reverse transcription-polymerase chain reaction (RT-PCR). The IMHRs gradually increased from 1 to 14 weeks in both groups (vs. 1 wk in each group, $p<0.05$ ). The IMHRs of the Graft plus ACEI group were comparable to those of Graft Alone group at 1 week, but significantly lower at 8 and 14 weeks (vs. Graft Alone group, $p<0.05$ ). The TGF- $\beta 1$ mRNA expression levels of the Graft plus ACEI group were clearly lower than those of the Graft Alone group at 1 and 8 weeks (vs. Graft Alone group, $p<0.05$ ), but similar at 14 weeks. TGF- $\beta 1$ in the synthetic artery graft of the Graft Alone group was up-regulated as early as 1 week after the operation, when no definitive development of a quantifiable neointima was observed. The TGF- $\beta 1$ mRNA expression of the Graft Alone group was highest at 8 weeks and lowest at 14 weeks (vs. 1 week, ${ }^{*} p<0.05$ ), but such time-dependent changes were not observed in the Graft plus ACEI group. The results indicated that ACEI reduced intimal hyperplasia in the grafts of the Graft plus ACEI group and also suppressed TGF- $\beta 1$ mRNA expression in perianastomotic intimal hyperplasia tissues to the normal artery level. Perianastomotic intimal hyperplasia in synthetic arterial graft is considered to be related to TGF- $\beta 1$, the expression of which is locally mediated by angiotensin II and, therefore, suppressed by ACEI.
\end{abstract}

Key words angiotensin-converting enzyme inhibitors, transforming growth factor beta, tunica intima, rabbits, polytetrafluoroethylene, carotid arteries

Received for publication September 7, 2004

Corresponding author: CHUNG WUNG WHANG, M.D., Department of Surgery, Korea University Medical Center, Korea University College of Medicine, 120-1, 5-ka, Anam-Dong, Sungbuk-Gu, Seoul 136-705, Korea. Tel: +82-31-412-5952 Fax: +82-31-413-4829 E-mail: junwonum @korea.ac.kr

Abbreviations: ACE, angiotensin-converting enzyme; ACEI, angiotensin-converting enzyme inhibitor; b-FGF, basic fibroblast growth factor; ECM, extracellular matrix; MHR, intima to media height ratio; PDGF, platelet derived growth factor; PTFE, polytetrafluoroethylene; RT-PCR, reverse transcription-polymerase chain reaction; SMC, smooth muscle cell; TGF- $\beta 1$, transforming growth factor- $\beta 1$, VEGF, vascular endothelial growth factor. 


\section{INTRODUCTION}

Intimal hyperplasia due to vascular smooth muscle cell (SMC) proliferation is a major cause of late vascular graft failure [1]. Diffuse fibrous thickening of the inner capsule, which results from SMC hyperplasia, is responsible for the $30 \%$ to $50 \%$ or greater failure rate seen in grafts less than $8 \mathrm{~mm}$ in diameter [2]. Intimal hyperplasia is of great prognostic importance for autologous vein grafts and synthetic grafts. Although intimal fibrous hyperplasia is often diffuse in vein grafts, synthetic vascular prostheses tend to develop intimal hyperplasia predominantly at the anastomoses [2]. Intimal hyperplasia is an exaggeration of the normal arterial healing response, arising from the intimal migration and proliferation of medial SMCs derived from the host vessels into a nonviable vascular graft [3].

The local renin-angiotensin system in vessels is activated by vascular injury such as balloon-catheter injury, autogenous or synthetic grafting. The production of local angiotensin II by this system stimulates hypertrophic growth and migration of vascular SMCs through a number of angiotensin II receptors in vascular wall [4-6]. Accompanying intimal hypertrophic growth, angiotensin II induces the expression of growth-related proto-oncogenes (c-fos, c-jun, and cmyc) and play a role in the synthesis of autocrine growth factors such as platelet derived growth factor (PDGF), transforming growth factor- $\beta 1$ (TGF- $\beta 1)$ as well as in promoting structural changes of the vascular wall $[7,8]$.

Growth factors that are related to the proliferation and migration of vascular SMCs in in vitro analysis are basic fibroblast growth factor (b-FGF), PDGF, TGF- $\beta 1$ and vascular endothelial growth factor (VEGF) [9-11]. TGF- $\beta 1$, which is known to influence SMC growth in vascular wall, has been a particular target for experimental research as a cause of intimal hyperplasia. It has been reported in in vitro studies that autocrine production of TGF- $\beta 1$ may mediate the growth modulatory effects of angiotensin II and TGF- $\beta 1$ seems to have multifunctional effects on the vascular SMCs $[8,12,13]$. Although a great deal of information is available regarding growth factors and their secretion by cells in culture, there have been only limited in vivo studies exploring the roles of these growth factors in the regulation of SMC proliferation during growth and development of normal arteries or in the process of artificial blood vessel occlusion.

Therefore this study was designed to investigate a possible involvement of angiotensin II and TGF- $\beta 1$ in perianastomotic intimal hyperplasia after synthetic arterial grafting and to examine the effect of ACE inhibitor on the development of intimal hyperplasia.

\section{MATERIALS AND METHODS}

\section{Animal preparation}

Subjects were 30 New Zealand White rabbits (Oryctolagus cuniculus), weighing 3.0 to $3.5 \mathrm{~kg}$. Animals were fed normal chow during the entire period of study. Animal care complied with the "Principles of Laboratory Animal Care" as formulated by the Korea University Animal Care and Use Committee, and the "Guide for the Care and Use of Laboratory Animals" (Department of Health and Human Services, NIH Publication No. 80-23, revised 1985). The 30 rabbits were randomly divided into two groups: 1. Fifteen rabbits were treated with the ACE inhibitor Captopril (10 $\mathrm{mg} / \mathrm{kg} / \mathrm{day}$ per os, Sigma, St. Louis, MO, USA) in drinking water, and the other 15 rabbits were treated with saline as a vehicle in drinking water for 7 days prior to the grafting operation. 2. Polytetrafluoroethylene (PTFE), (Gore-Tex, W. L. Gore \& Associates, Inc. Newark, DE, USA) bypass grafts were interposed in the right carotid artery of all 30 rabbits. 3. After the bypass graft operations, 15 rabbits were given Captopril for 1,8 , or 14 weeks (Graft plus ACEI group), and the remaining 15 rabbits were given saline as a vehicle for the same periods (Graft Alone group).

\section{Graft implantation and harvest}

All surgical procedures were performed under sterile conditions. Rabbits were anesthetized with a single dose of $100 \mathrm{mg} / \mathrm{kg}$ of ketamine hydrochloride intramuscularly prior to the operation and the anesthesia was maintained by intermittent intravenous injections of $5 \mathrm{mg} / \mathrm{kg}$ of ketamine during the operation. Expanded PTFE, 3-mm in internal diameter and $10-\mathrm{mm}$ in length, was used as a synthetic graft. The PTFE graft was implanted in the right common carotid artery by 8 to 10 interrupted sutures and endto-end anastomosis with 9-0 monofilament nylon (ethilon) (Ethicon, Edinburgh, UK) under a microscope. No anticoagrant was given prior to the operation, but a single dose of Gentamicin $(2 \mathrm{mg} / \mathrm{kg})$ was injected intramuscularly as a prophylactic antibiotic.

The two groups (Graft Alone and Graft plus ACEI) were further divided into three subgroups according to the period from PTFE grafting to the 
harvest day; i.e. 1,8 or 14 weeks. The implanted grafts were harvested along with the contra-lateral normal carotid arteries of the Graft Alone group. A $20-\mathrm{mm}$ length of carotid artery, including the $10-\mathrm{mm}$ PTFE graft and 5-mm margins from both the proximal and distal anastomoses was collected. For harvest, rabbits were anesthetized as described previously. All the grafts were examined with a Doppler signal detector to evaluate the graft patency during harvest. Finally the animals were euthanized. The adjacent soft tissues around the graft were completely removed to reduce the possible noise from such tissues. The harvested PTFE graft tissues and the contra-lateral normal arteries harvested were cut in half in a longitudinal fashion with micro-scissors; one half was immediately immersed in liquid nitrogen and stored at $-80^{\circ} \mathrm{C}$ for later reverse transcription-polymerase chain reaction (RT-PCR) study, and the other half was stored in $10 \%$ Formalin solution for histological examination and morphometric analysis.

\section{Histology and morphometric analysis}

Intimal hyperplasia was evaluated in terms of the intima to media height ratio (IMHR). The removed PTFE grafts and normal carotid arteries were treated in $10 \%$ formalin and paraffinized by routine methods. Three 5- $\mu \mathrm{m}$ consecutive paraffin sections of the specimen were stained with hematoxylin and eosin, modified Masson's Trichrome and elastic stain, and then examined at magnifications of $40,100,200$, and 400 by light microscopy. Intimal hyperplasia was quantified morphometrically by measuring the IMHRs. The IMHR was determined as the vertical depth of the intimal thickness over the media at the proximal anastomosis sites on photographs. The intimal thickness and the thickness of the media were defined as the length of the perpendicular line between the inner surface of the intima and the internal elastic lamina, and the length of the perpendicular line between the internal elastic lamina and the outer smooth muscle layer, respectively. Two independent reviewers performed the morphometric measurements on each photograph.

\section{$R N A$ extraction and TGF- $\beta 1 \mathrm{mRNA}$ expression}

Total cellular RNA was isolated using Qiagen RNeasy Mini Kit (QIAGEN GmbH Hilden, Germany). The samples, the perianastomotic tissues of PTFE grafts or the contra-lateral normal arteries from the Graft Alone group, were disrupted and lysed in RNeasy lysis buffer (Buffer RLT) contain- ing guanidium isothiacynate with the aid of a tissue homogenizer (Model 7725-13, CORNING, NY, USA). Ethanol was then added to the lysate to adjust the binding condition of RNA to the RNeasy membrane. The lysate was then applied to the RNeasy mini spin column; the total RNA was adsorbed on the membrane inside the column. The membrane was washed with the RNase-free Buffer three times to remove contaminants, and then total RNA was eluted in RNase-free water. RNA was quantified spectrophotometrically by absorbance at $260 \mathrm{~nm}$.

\section{cDNA synthesis by reverse transcription ( $R T)$}

Oligo dT-primed 1st strand cDNA was synthesized from the template RNA $(1 \mu \mathrm{g})$ using cDNA Synthesis Kit (Boehringer Mannheim, Indianapolis, IN, USA).

\section{Polymerase chain reaction (PCR)}

The cDNA template was mixed with the sense and anti-sense oligonucleotide primers specific for TGF- $\beta 1$ and glyceraldehyde- 3-phosphate dehydrogenase (GAPDH) and subjected to PCR. The sequences of the TGF- $\beta 1$ sense and anti-sense primers were (5'-CTTCAGCTCCACAGAGAAG AACTGC-3') and (5'-CACGATCATGTTGCACACTGCTCC-3'), respectively. The sequences of the GAPDH sense and anti-sense primers were (5'CCATGTTCGTCATGGGTG-TGAACCA-3') and (5'-CATGAGTCCTTCCACGATACCAAAG-3'), respectively.

The PCR mixture at a final volume of $50 \mu \mathrm{l}$ contained $4 \mu \mathrm{l}$ of template cDNA and 25 pmol of each primer. The PCR reactions were performed on a Perkin Elmer Cetus DNA Thermal Cycler (Model 2400, Norwalk, CT, USA). The reaction for GAPDH was initiated at $94{ }^{\circ} \mathrm{C}$ for $10 \mathrm{~min}$. Then a total of 35 cycles were done with denaturing at $94^{\circ} \mathrm{C}$ for $45 \mathrm{sec}$, annealing at $52^{\circ} \mathrm{C}$ for $45 \mathrm{sec}$, and extension at $72^{\circ} \mathrm{C}$ for $45 \mathrm{sec}$. In the reaction for TGF- $\beta 1$, PCR was initiated at $94{ }^{\circ} \mathrm{C}$ for $5 \mathrm{~min}$. Then a total of 45 cycles were done with denaturing at $94{ }^{\circ} \mathrm{C}$ for $45 \mathrm{sec}$, annealing at $50{ }^{\circ} \mathrm{C}$ for $45 \mathrm{sec}$, and extension at $72{ }^{\circ} \mathrm{C}$ for $45 \mathrm{sec}$.

\section{Electrophoresis}

The PCR products ( 5 and $18 \mu \mathrm{l}$ for GAPDH and TGF- $\beta 1$, respectively) were analyzed by a $2.0 \%$ agarose gel electrophoresis, stained with ethidium bromide, visualized with UV light and photographed. Photographs were scanned using Epson GT-9500 (Seiko, Tokyo, Japan) and measured by a densitome- 
ter (Image PC alpha 9, NIH, Bethesda, MD, USA).

\section{Statistical analysis}

The data were expressed as the mean \pm the standard error of the mean (SEM). Statistical differences between groups were tested with Student t test, oneway analysis of variance, or the Student-NewmanKeuls test. A $p$ value of less than 0.05 was regarded as significant.

\section{RESULTS}

\section{Graft patency and histological findings}

The two groups (Graft Alone and Graft plus ACEI) were further divided into three subgroups according to the periods from PTFE grafting to the harvest days; 1,8 and 14 weeks. Two grafts were excluded from this study because of primary graft failure; one was from the Graft Alone group at 1 week and the other was from the Graft plus ACEI group at 8 weeks. The graft patency rates in the two groups were $80-100 \%$ and there was no significant difference between them. Thus a total of 28 rabbits were available for the measurement of IMHRs and TGF- $\beta 1$ mRNA expression. As shown in Fig. 1, the PTFE grafts implanted in the carotid artery showed wall-thickening with neointima formation. The neointima first appeared at 1 week and it gradually thickened throughout the study period.

\section{IMHR}

Table 1 shows the results of the IMHR measure. There was no difference in IMHRs between Graft
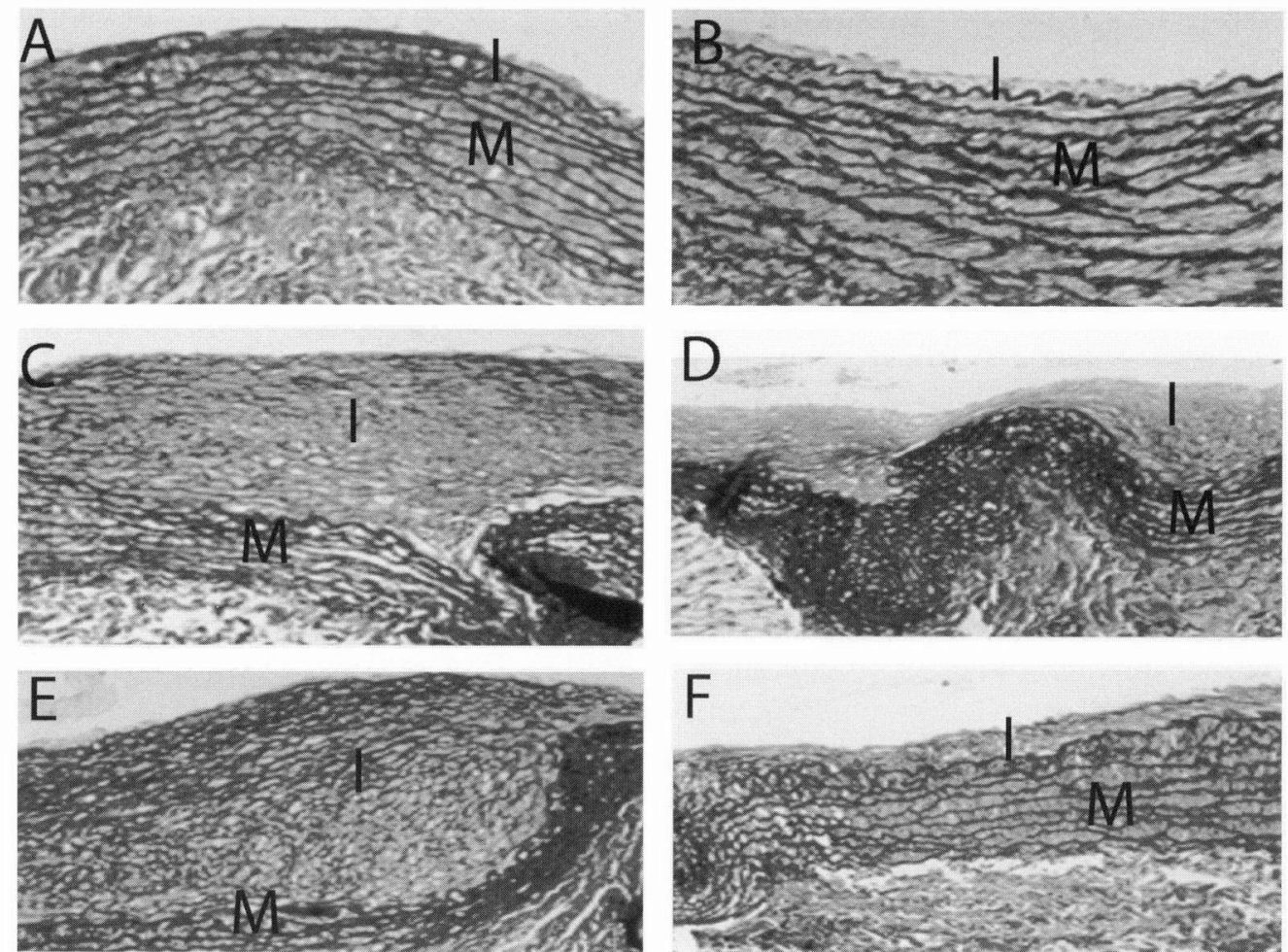

Fig. 1. Time-dependent changes of intima. A. Graft Alone group, 1 week after implantation, showing a single layer of endothelium in intimal portion at anastomosis site; $\mathbf{B}$. Graft plus ACEI group, 1 week after implantation, showing a single layer of endothelium in intimal portion. The intimal thickness showed no difference with that of Graft Alone group (A); C. Graft Alone group, 8 weeks after implantation, showing more thickened and well organized intimal portion compared to the intimal portion of Graft Alone group at 1week (A); D. Graft plus ACEI group, 8 weeks after implantation, showing clearly suppressed intimal hyperplasia compared to Graft Alone group at 8 weeks (C); E. Graft Alone group, 14 weeks after implantation, exhibiting markedly thickened intima with abundant proliferation of smooth muscle cells and fibrous tissues at anastomosis site; F. Graft plus ACEI group, 14 weeks after implantation, showing markedly decreased intima. I: intima, M: media. magnification, $100 \times$. hematoxylin and eosin stain. 
Alone and Graft plus ACEI group at 1 week. However, IMHRs of the Graft plus ACEI group were significantly lower than those of the Graft Alone group at 8 and 14 weeks $(p<0.05)$. The IMHRs increased over time from 1 to 14 weeks in both groups ( $p<0.05$, see also Fig. 1).

\section{The TGF- $\beta 1$ mRNA expression}

Expression level of TGF- $\beta 1$ mRNA was normalized for GAPDH mRNA, and the time-dependent

TABLE 1.

The IMHRS

\begin{tabular}{cccc}
\hline $\begin{array}{c}\text { Postoperative interval } \\
\text { (weeks) }\end{array}$ & Graft Alone & Graft plus ACEI & $p$ value \\
\hline 1 & $0.09 \pm 0.02$ & $0.08 \pm 0.02$ & $\mathrm{NS}^{*}$ \\
8 & $0.71 \pm 0.05$ & $0.30 \pm 0.08$ & $<0.05$ \\
14 & $1.36 \pm 0.14$ & $0.53 \pm 0.07$ & $<0.05$ \\
\hline$p$ value & $<0.05$ & $<0.05$ & \\
\hline
\end{tabular}

t-test: comparison between the Graft Alone and the Graft plus ACEI group.

ANOVA: comparison according to post-operative interval in each group.

*NS: not significant

A Graft Only Graft / ACEI Normal Artery

TGF- $\beta 1$

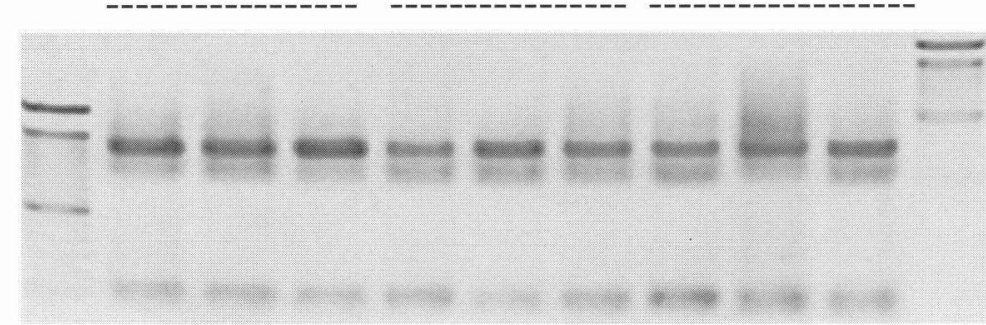

B

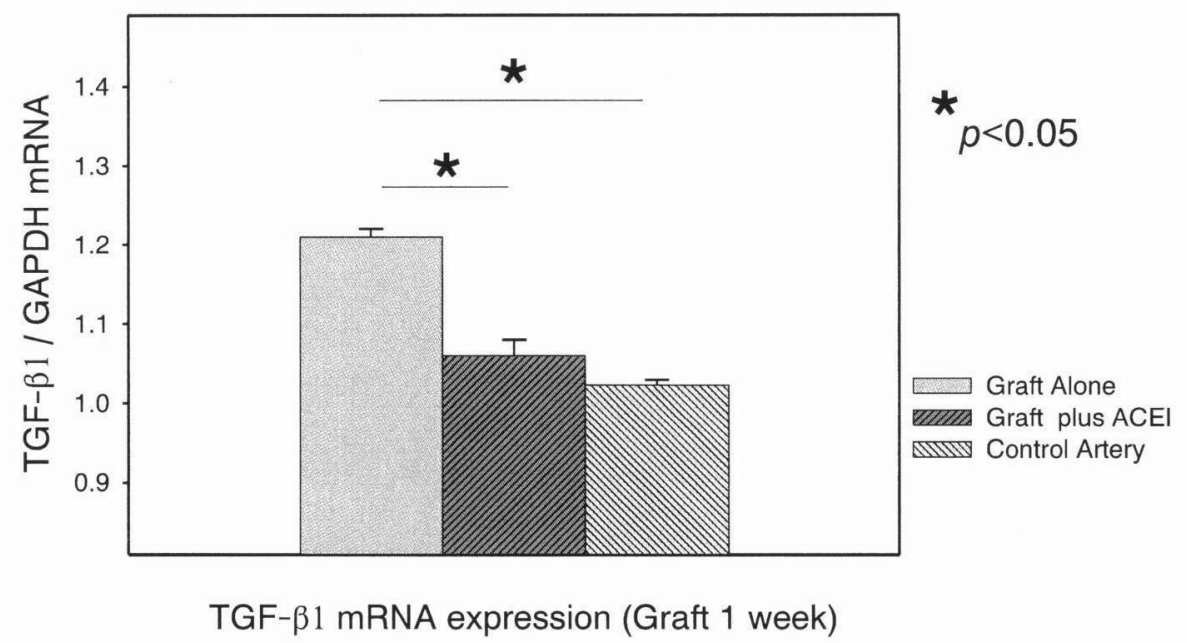

Fig. 2. Expression of TGF- $\beta 1$ mRNA in the Graft Alone and Graft plus ACEI groups at 1 week. A. agarose gel electrophoresis. TGF- $\beta$ 1, 298 bp-band and GAPDH, 149 bp-band. B. Ratios of the expression levels of TGF- $\beta 1$ mRNA to GAPDH mRNA. 
A

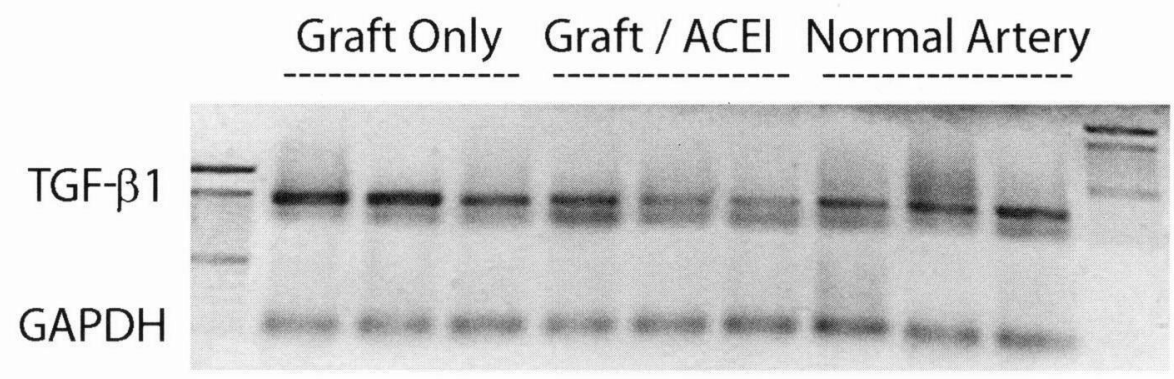

B

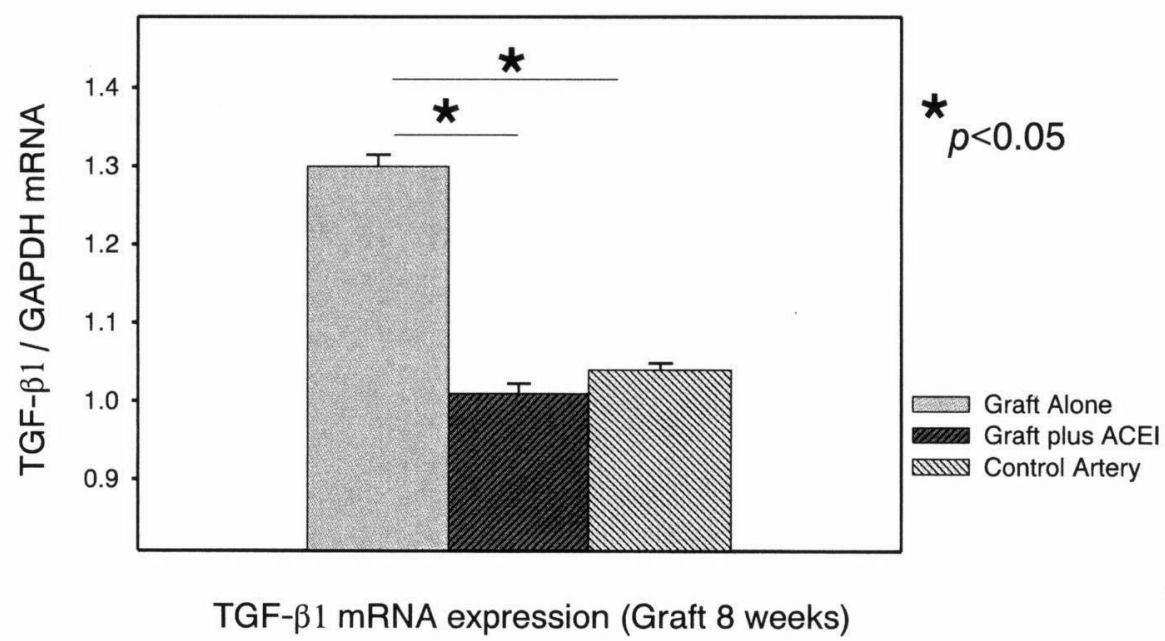

Fig. 3. Expression of TGF- $\beta 1$ mRNA in the Graft Alone and Graft plus ACEI groups at 8 weeks. A. agarose gel electrophoresis. B. Ratios of the expression levels of TGF- $\beta 1$ mRNA to GAPDH mRNA.

changes of TGF- $\beta 1$ mRNA expression in the graft tissues were compared with those in the control arteries (Figs 2 and 3).

Graft at 1 week: TGF- $\beta 1$ expression in the Graft plus ACEI group was lower than that in the Graft Alone group (vs. Graft Alone; $* p<0.05$ ). There were no differences in expression between Graft plus ACEI and the control arteries (Fig. 2).

Graft at 8 weeks: TGF- $\beta 1$ expression in the Graft plus ACEI group was lower than that in the Graft Alone group (vs. Graft Alone; $* p<0.05$ ). There were no differences in expression between Graft plus ACEI and the control arteries (Fig. 3).

Graft at 14 weeks: There were no differences among the Graft plus ACEI group, the Graft Alone group and the control arteries.

Time-dependent changes: TGF- $\beta 1$ mRNA in the Graft Alone group increased from week 1 to week 8 $(p<0.05)$, and then decreased from week 8 to week $14(p<0.05)$. The expression level was highest at 8 weeks and lowest at 14 weeks. No such time-dependent changes were observed in the Graft plus ACEI group.

\section{DISCUSSION}

Proliferation and migration of vascular SMCs followed by accumulation of extracellular matrix $(\mathrm{ECM})$ in the intima after vascular graft procedures is known as a major cause of intimal hyperplasia in both clinical and experimental settings $[2,13,14]$. The accumulation of ECM in the vascular system plays an important role in the vascular hypertrophy and restenosis after grafting as well as in development of myocardial infarction and hypertension [15]. It has been suggested by in vitro studies $[9-11,16,17]$ that proliferation and migration of vascular SMC and accumulation of ECM are controlled by number of growth factors.

Local angiotensin II and TGF- $\beta 1$ are known to 
play a role in signaling the abnormal accumulation of ECM in vascular disease [15]. TGF- $\beta 1$ has been implicated as a causative factor in accumulation of ECM in the intima, leading to progressive thickening of the intima (intimal hyperplasia) $[13,18,19]$. It has been demonstrated that accumulation of ECM components in neointimal lesions is at least partly due to autocrine TGF- $\beta 1$ activity in vascular SMCs [13]. Hoch et al. [20] observed remarkably early up-regulation of TGF- $\beta 1$ and PDGF-A mRNA expression in vein graft arterializations before the development of quantifiable intimal hyperplasia. The TGF- $\beta 1$ gene expression continued to increase during the development of intimal hyperplasia for 2 weeks, whereas the PDGF-A gene expression decreased. Our data showed that TGF- $\beta 1$ mRNA expression in the Graft Alone group increased from weeks 1 to 8 and decreased thereafter. Therefore we consider that TGF- $\beta 1 \mathrm{mRNA}$ expression was up-regulated in the early period, continued to increase at least 8 weeks after grafting and then was down-regulated possibly by a mechanism as negative feed back. Autocrine TGF- $\beta 1$ activity appears to be one of the important determinants of vascular SMC growth in hypertrophy or hyperplasia [12]. Proliferation and migration of SMC and accumulation of ECM, however, may be also stimulated by other growth factors.

Angiotensin influences vascular tone via its receptors on the vessel wall. The renin-angiotensin system is suggested to be active in vascular walls $[5,21,22]$. It has been demonstrated that local angiotensin II is involved in the proliferative response of vascular wall after arterial injury and directly causes vascular hypertrophy independent of systemic factors and hemodynamic effects [23]. The role of local angiotensin II in the vascular system was investigated by administration of ACE inhibitor, which prevented a proliferative response (neointima formation) after coronary angioplasty and vascular surgery $[5,6,15,24-26]$.

Captopril, a sulfhydryl-containing ACE inhibitor, has been shown to protect cultured endothelial cells from free radical injury [25,27] and to have an antiatherogenic effect in heritable hyperlipidemic rabbits and cholesterol-fed monkeys $[28,29]$. The dose of Captopril, $10 \mathrm{mg} / \mathrm{kg} / \mathrm{day}$, adopted in our rabbit study was approximately twice that typically used in humans. However it has been shown that rabbits require up to 10 times the dose of Captopril to achieve the same degree of ACE inhibitory effect as that generally attained in humans [30]. Further, there was no difference in blood pressure between rabbit groups, the control group and the chronically Captopril-administered (10 mg/kg/daily) group [31]. In a vein graft experiment, chronic ACE inhibition was found to reduce intimal hyperplasia [32], which is consistent with our results in this arterial synthetic graft model.

The angiotensin II is known as a bifunctional modulator for vascular SMC growth, capable of inducing hypertrophy or inhibiting mitogen-stimulated DNA synthesis $[5,8,12,15,20,33]$. It has been shown by in vitro study that angiotensin II induces TGF- $\beta 1$ gene expression via a protein kinase Cdependent pathway involving de novo protein synthesis, promotes the conversion of latent TGF- $\beta 1$ to its biologically active form, and modulates vascular SMC growth by activating both proliferative and anti-proliferative pathways [12]. On the other hand, in the growth response of vascular SMC to angiotensin II, TGF- $\beta 1$ was reported to have an antiproliferative affect and to modulate the mitogenic properties of b-FGF. An imbalance in signals activated by angiotensin II may result in abnormal vascular SMC growth, leading to the development of vascular disease [8]. The present study suggested that autocrine activity of TGF- $\beta 1$ increased in the early period and then decreased after 8 weeks in the Graft Alone group. In the Graft plus ACEI group, the ACE inhibitor appeared to suppress the autocrine activity of TGF- $\beta 1$ in the early period and that its function was maintained until 8 weeks. This in vivo study showed that TGF- $\beta 1 \mathrm{mRNA}$ expression had already increased at around 1 week, although there was no difference in quantifiable intimal hyperplasia between the two groups at this time, and TGF- $\beta 1 \mathrm{mRNA}$ expression in the Graft plus ACEI group was significantly lower than that of Graft Alone at 1 and 8 weeks. In contrast to the Graft Alone group, no significant sequential time-dependent changes of TGF$\beta 1$ mRNA expression were observed in the Graft plus ACEI group, and there was no difference in TGF- $\beta 1$ mRNA expression between the Graft plus ACEI group and the control artery. These results indicated that intimal hyperplasia is related to TGF$\beta 1$ and angiotensin II in the early period and the ACE inhibitor may suppress TGF- $\beta 1$ mRNA expression for the first 8 weeks after the operation. Although IMHRs of the Graft plus ACEI group were significantly lower than those of the Graft Alone group at 14 weeks, there was no difference in mRNA expression of TGF- $\beta 1$ between the two groups at that time.

Recently TGF- $\beta 1$ was related to subnormal wall 
shear stress [34], vascular smooth muscle cells including type I collagen [35], continuous arterial pressure [36], high dose external radiation [37], and macrophages with their cytokines [38] in various models of intimal hyperplasia. ACE inhibitors also reduced intimal hyperplasia in various studies $[39,40]$.

Therefore, these receptors for TGF- $\beta 1$ may participate in modulating the proliferative response of the vascular wall after vascular graft, and further studies at the receptor level are needed to clarify the time-dependent change of TGF- $\beta 1$ expression.

This study strongly indicated that the early activation of TGF- $\beta 1$ is associated with intimal hyperplasia and that there is also relationship between angiotensin II and TGF- $\beta$ 1. Angiotensin II and TGF- $\beta 1$ may be involved in one of the pathways that mediate intimal hyperplasia in vascular grafts. ACE inhibition can reduce mRNA expression of TGF- $\beta 1$, and ACE inhibitors may be useful to inhibit intimal hyperplasia in vascular graft procedures.

\section{REFERENCES}

1. Berkowitz HD, Greenstein S, Barker CF, and Perloff LJ Late failure of reversed vein bypass grafts. Ann Surg 1989; 210:782-786

2. Schoen FJ, and Castellot JJ, Jr. Vascular graft intimal fibrous hyperplasia: prospects for pharmacological inhibition. J Vasc Surg 1991; 13:758-761.

3. Clowes AW, Kirkman TR, and Reidy MA. Mechanisms of arterial graft healing. Rapid transmural capillary ingrowth provides a source of intimal endothelium and smooth muscle in porous PTFE prostheses. Am J Pathol 1986; 123:220-230.

4. Oliver JA, and Sciacca RR. Local generation of angiotensin II as a mechanism of regulation of peripheral vascular tone in the rat. J Clin Invest 1984; 74:12471251.

5. Dzau VJ. Vascular renin-angiotensin: a possible autocrine or paracrine system in control of vascular function. J Cardiovasc Pharmacol 1984; 6:S377-S382.

6. Osterrieder W, Muller RK, Powell JS, Clozel JP, Hefti F et al. Role of angiotensin II in injury-induced neointima formation in rats. Hypertension 1991; 18:II60-II64.

7. Naftilan AJ, Pratt RE, Eldridge CS, Lin HL, and Dzau VJ. Angiotensin II induces c-fos expression in smooth muscle via transcriptional control. Hypertension 1989; 13:706-711.

8. Itoh H, Mukoyama M, Pratt RE, Gibbons GH, and Dzau VJ. Multiple autocrine growth factors modulate vascular smooth muscle cell growth response to angiotensin II. J Clin Invest 1993; 91:2268-2274.

9. Ross R, Raines EW, and Bowen-Pope DF. The biology of platelet-derived growth factor. Cell 1986; 46:155-169.

10. Golden MA, Au YP, Kirkman TR, Wilcox JN, Raines
EW et al. Platelet-derived growth factor activity and mRNA expression in healing vascular grafts in baboons. Association in vivo of platelet-derived growth factor mRNA and protein with cellular proliferation. J Clin Invest 1991; 87:406-414

11. Zacharias RK, Kirkman TR, Kenagy RD, Bowen-Pope $\mathrm{DF}$, and Clowes AW. Growth factor production by polytetrafluoroethylene vascular grafts. J Vasc Surg 1988; 7:606-610.

12. Gibbons GH, Pratt RE, and Dzau VJ. Vascular smooth muscle cell hypertrophy vs. hyperplasia. Autocrine transforming growth factor-beta 1 expression determines growth response to angiotensin II. J Clin Invest 1992; 90:456-461.

13. Rasmussen LM, Wolf YG, and Ruoslahti E. Vascular smooth muscle cells from injured rat aortas display elevated matrix production associated with transforming growth factor-beta activity. Am J Pathol 1995; 147:10411048.

14. Clowes AW, and Reidy MA. Mechanisms of arterial graft failure: the role of cellular proliferation. Ann NY Acad Sci 1987; 516:673-678.

15. Ju H, and Dixon IM. Extracellular matrix and cardiovascular diseases. Can J Cardiol 1996; 12:1259-1267.

16. Golden MA, Au YP, Kenagy RD, and Clowes AW. Growth factor gene expression by intimal cells in healing polytetrafluoroethylene grafts. J Vasc Surg 1990; 11:580-585.

17. Gibbons GH, and Dzau VJ. The emerging concept of vascular remodeling. N Engl J Med 1994; 330:14311438.

18. Border WA, and Noble NA. Transforming growth factor beta in tissue fibrosis. N Engl J Med 1994; 331:12861292.

19. Wolf YG, Rasmussen LM, and Ruoslahti E. Antibodies against transforming growth factor-beta 1 suppress intimal hyperplasia in a rat model. J Clin Invest 1994; 93:1172-1178.

20. Hoch JR, Stark VK, and Turnipseed WD. The temporal relationship between the development of vein graft intimal hyperplasia and growth factor gene expression. $\mathrm{J}$ Vasc Surg 1995; 22:51-58.

21. Rosenthal JH, Pfeifle B, Michailov ML, Pschorr J, Jacob IC et al. Investigations of components of the reninangiotensin system in rat vascular tissue. Hypertension 1984; 6:383-390.

22. Dzau VJ. Implications of local angiotensin production in cardiovascular physiology and pharmacology. Am J Cardiol 1987; 59:59A-65A.

23. Morishita R, Gibbons GH, Ellison KE, Lee W, Zhang L et al. Evidence for direct local effect of angiotensin in vascular hypertrophy. In vivo gene transfer of angiotensin converting enzyme. J Clin Invest 1994; 94:978-984.

24. Powell JS, Clozel JP, Muller RK, Kuhn H, Hefti F et al. Inhibitors of angiotensin-converting enzyme prevent myointimal proliferation after vascular injury. Science 1989; 245:186-188.

25. Mak IT, Freedman AM, Dickens BF, and Weglicki WB. Protective effects of sulfhydryl-containing angiotensin converting enzyme inhibitors against free radical injury 
in endothelial cells. Biochem Pharmacol 1990; 40:21692175.

26. Clozel JP, Powell JS, Kuhn H, Muller RK, Hefti F et al. Vascular protection with cilazapril. Drugs 1991; 41:6267.

27. Chopra M, Scott N, McMurray J, McLay J, Bridges A et al. Captopril: a free radical scavenger. $\mathrm{Br} \mathrm{J}$ Clin Pharmacol 1989; 27:396-399.

28. Chobanian AV, Haudenschild CC, Nickerson C, and Drago R. Antiatherogenic effect of captopril in the Watanabe heritable hyperlipidemic rabbit. Hypertension 1990; 15:327-331.

29. Aberg G, and Ferrer P. Effects of captopril on atherosclerosis in cynomolgus monkeys. J Cardiovasc Pharmacol 1990; 15:S65-S72.

30. Meredith PA, Elliott HL, Donnelly R, and Reid JL. Dose-response clarification in early drug development. $\mathrm{J}$ Hypertens Suppl 1991; 9:S356-S357.

31. O'Donohoe MK, Schwartz LB, Radic ZS, Mikat EM, McCann RL et al. Chronic ACE inhibition reduces intimal hyperplasia in experimental vein grafts. Ann Surg 1991; 214:727-732.

32. Ebner R, Chen RH, Lawler S, Zioncheck T, and Derynck R. Determination of type I receptor specificity by the type II receptors for TGF-beta or activin. Science 1993; 262:900-902.

33. Geisterfer AA, Peach MJ, and Owens GK. Angiotensin II induces hypertrophy, not hyperplasia, of cultured rat aortic smooth muscle cells. Circ Res 1988; 62:749-756.

34. Sho M, Sho E, Singh TM, Komatsu M, Sugita A et al.
Subnormal shear stress-induced intimal thickening requires medial smooth muscle cell proliferation and migration. Exp Mol Pathol 2002; 72:150-160.

35. Kubota K, Okazaki J, Louie O, Kent KC, and Liu B. TGF-beta stimulates collagen (I) in vascular smooth muscle cells via a short element in the proximal collagen promoter. J Surg Res 2003; 109:43-50.

36. Xiao M, You W, Yuan Z, and Xu G. Mechanism of intimal hyperplasia of venous grafts after coronary artery bypass grafting, an experimental study. Zhonghua Yi Xue Za Zhi 2002; 82:1550-1552.

37. Ducasse E, Cosset JM, Mazurier J, Eschwege F, Puppinck $P$ et al. High-dose external ionizing radiation prevents intimal hyperplasia and limits secretion of growth factors PDGF, bFGF, and TGF- $\beta 1$. Experiments and results. J Mal Vasc 2003; 28:68-72.

38. Wolff RA, Tomas JJ, Hullett DA, Stark VE, van Rooijen $\mathrm{N}$ et al. Macrophage depletion reduces monocyte chemotactic protein-1 and transforming growth factor-betal in healing rat vein grafts. J Vasc Surg 2004; 39:878-888.

39. Okumura K, Sone T, Kondo J, Tsuboi H, Mukawa H et al. Quinapril prevents restenosis after coronary stenting in patients with angiotensin-converting enzyme $\mathrm{D}$ allele. Circ J 2002; 66:311-316.

40. Kim S, Izumi Y, Izumiya Y, Zhan Y, Taniguchi M et al. Beneficial effects of combined blockade of ACE and AT1 receptor on intimal hyperplasia in balloon-injured rat artery. Arterioscler Thromb Vasc Biol 2002; 22:12991304. 